\title{
Cymbopogon schoenanthus Oil
}

National Cancer Institute

\section{Source}

National Cancer Institute. Cymbopogon schoenanthus Oil. NCI Thesaurus. Code

C107299.

The essential oil of Cymbopogon schoenanthus. Cymbopogon schoenanthus oil is used for its aromatic properties. 